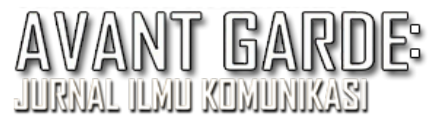

9-15Sก: $23333-4,31 \%$

$9-155 N^{2} 235 \%-151 \%$

\title{
Pengalaman Komunikasi dan Adopsi Teknologi Komunikasi dalam Menjalankan Organisasi Mahasiswa selama Pandemi Covid-19
}

\author{
Kholidil Amin \\ kholidilamin@gmail.com \\ Universitas Padjadjaran, J1. Raya Bandung Sumedang KM.21, Kabupaten Sumedang, Indonesia
}

Submitted: 25 Maret 2021, Revised: 11 April 2021, Accepted : 23 April 2021

\begin{abstract}
Abstrak
Pandemi Covid-19 yang berlangsung lama mengharuskan organisasi, termasuk BEM FISIP Universitas Brawijaya sebagai organisasi mahasiswa, untuk beradaptasi agar program kerja organisasinya dapat berjalan. Perubahan cara kerja organisasi terjadi dalam hal pelaksanaan program kerja, cara berkoordinasi, dan aktivitas-aktivitas keakraban antar anggota yang harus dilakukan secara daring dengan mengadopsi teknologi komunikasi. Beberapa riset terdahulu menjelaskan situasi pandemi membuat individu mengalami pengalaman komunikasi masing-masing yang subjektif dalam merespon pandemi. Menggunakan paradigma interpretif dan metode fenomenologi, penelitian ini berupaya menjelaskan apa dan bagaimana pengalaman pengurus organisasi dalam menjalankan organisasinya selama pandemi Covid-19. Penelitian ini juga bertujuan untuk menjelaskan apa kendala yang dialami dan bagaimana mengatasi kendala di organisasi selama pandemi Covid-19. Hasil penelitian mengungkapkan bahwa pengurus organisasi menganggap ada kekurangan dan kelebihan dalam menjalankan organisasinya selama pandemi. Penelitian ini juga menemukan bahwa pengurus mengalami kendala namun mereka memiliki solusi yang adaptif menghadapi pandemi. Temuan lainnya juga adalah ada perbedaan pengalaman dalam menjalankan aktivitas organisasi oleh pengurus yang menganggap dirinya introver dan ekstrover.
\end{abstract}

Kata kunci: covid-19, pandemi, pengalaman komunikasi, organisasi.

\section{Experience of Communication and Communication Technology Adoption in Running Student Organizations During The Covid-19 Pandemic}

\begin{abstract}
The Covid-19 pandemic that has lasted a long time requires organizations, including BEM FISIP Universitas Brawijaya as a student organization, to adapt to running their organizational work programs. Changes in the way organizations work occur in implementing work programs, ways of coordination, and friendship activities between members that must be carried out online by adopting communication technology. Some previous research has explained that a pandemic situation makes individuals have subjective communication experiences in response to a pandemic. Using an interpretive paradigm and phenomenology, the present research seeks to explain what organizational management experience in running their organizations during the Covid-19 pandemic. The present study also aims to explain what obstacles are experienced and how to overcome the organization's obstacles during the Covid-19 pandemic. The results revealed that the members experienced advantages and disadvantages in running the organization during the pandemic. The study found that the members experienced constraints; however, they have adaptive solutions to face the pandemic. Another finding is that there are different experiences in carrying out organizational activities by members who suppose they are introverts or extroverts.
\end{abstract}

Keywords: covid-19, experience of communication, pandemic, organization 


\section{PENDAHULUAN}

Menjalankan organisasi di tengah pandemi Covid-19 yang disebabkan oleh virus Corona adalah hal baru bagi organisasi, termasuk Badan Eksekutif Mahasiswa FISIP, Universitas Brawijaya periode 2020 (BEM FISIP) sebagai organisasi mahasiswa. Pandemi Covid-19 menjadi ancaman serius dan berisiko tinggi terhadap kesehatan sehingga membuat World Health Organization (WHO) mengeluarkan peringatan kepada negara-negara untuk mengantisipasi penyebaran virus ini (Sohrabi et al., 2020). Pandemi Covid-19 bukan hanya berdampak terhadap sektor kesehatan dan sektor ekonomi melainkan juga berdampak pada sektor pendidikan yang harus beradaptasi dengan cara belajar dan mengajar yang baru (Abidah et al., 2020), yakni harus dilakukan secara daring (Khasanah et al., 2020), termasuk juga kegiatan organisasi siswa di sekolah atau mahasiswa di universitas. Karena penyebaran Covid19 yang belum terkendali, otoritas kampus atau universitas membuat kebijakan seluruh aktivitas kemahasiswaan baik akademik maupun non-akademik harus dilakukan secara daring. Kebijakan ini berdampak kepada semua organisasi kemahasiswaan di kampus yang harus mengubah cara kerja organisasinya, termasuk BEM FISIP. Perubahan cara kerja organisasi terjadi dalam hal pelaksanaan program kerja, cara berkoordinasi, dan aktivitas-aktivitas keakraban antar anggota yang harus dilakukan secara daring.

Berdasarkan wawancara dengan Presiden BEM FISIP, program-program kerja BEM FISIP yang sejak awal periode kepengurusan direncanakan untuk digelar secara tatap muka, tiba-tiba di bulan Maret 2020 harus dirancang ulang karena pandemi Covid-19. Pengurus BEM FISIP langsung merancang ulang rencana program kerjanya yang memungkinkan dilaksanakan tanpa harus bertatap muka, dan tidak menimbulkan kerumunan orang. Namun, memang ada program-program kerja yang harus tetap dilaksanakan secara tatap muka seperti pengabdian masyarakat ke desa. Program-program kerja yang dilaksanakan secara daring memanfaatkan teknologi komunikasi seperti Zoom, Instagram, dan Spotify. Lebih lanjut, BEM FISIP juga langsung adaptif untuk memanfaatkan teknologi komunikasi guna mendukung jalannya koordinasi pelaksanaan program kerja organisasinya. Semua alur koordinasi antar pengurus dilakukan secara daring menggunakan aplikasi chatting seperti Whatsapp, dan aplikasi online meeting seperti Zoom (A.D Prasaja, wawancara pribadi, 1 Desember 2020).

Menjalankan organisasi dengan berbagai adaptasi karena pandemi Covid-19 adalah hal yang baru dialami oleh semua pengurus di BEM FISIP 2020. Berdasarkan wawancara yang dilakukan dengan pengurus BEM, mereka menjelaskan situasi ini awalnya membuat mereka terkejut dan bingung di awal terkait bagaimana kelanjutan program kerja organisasinya, namun seiring berjalannya waktu mereka mampu menemukan irama yang tepat, dan langkah yang jelas agar organisasinya terus berjalan dengan berbagai adaptasi yang baru. Situasi ini menjadi pengalaman khusus yang dialami oleh pengurus BEM FISIP 2020. Oleh karena itu, kajian mengenai pengalaman komunikasi pengurus BEM FISIP 2020 dalam menjalankan organisasi, dan adaptasi teknologi komunikasi selama pandemi ini menarik untuk diteliti.

Penelitian yang membahas tentang pengalaman individu khususnya pengalaman komunikasi selama pandemi Covid-19 telah dilakukan oleh beberapa peneliti sebelumnya menggunakan metode fenomenologi. Penelitian yang dilakukan oleh Prasetya \& Hidayat (2020) menemukan bahwa pekerja informal mengalami dampak negatif dan dampak positif dalam bekerja selama pandemi Covid-19. Situasi pandemi yang dirasakan juga membuat 
pekerja informal terbagi ke dalam dua karakteristik yakni pekerja yang merasa terpuruk dan pekerja yang mau mencari peluang di masa pandemi. Lebih lanjut, penelitian yang dilakukan oleh Hidayat \& Noeraida (2020) juga menemukan bahwa siswa merasakan kelemahan dan kelebihan sistem pembelajaran daring selama pandemi Covid-19. Situasi pandemi yang dirasakan juga membuat siswa terbagi dalam dua karakteristik yakni siswa yang merasa nyaman belajar daring dan siswa yang lebih ingin belajar tatap muka.

Penelitian yang dilakukan oleh Mustopa dan Hidayat (2020) juga mengungkapkan bahwa mahasiswa memiliki pengalaman yang subjektif terkait kekurangan dan kelemahan yang dialami oleh mahasiswa dari proses kelas daring selama pandemi Covid-19. Ketiga riset fenomenologi dalam konteks pandemi Covid-19 tersebut menggambarkan pengalaman komunikasi yang dialami oleh masing-masing individu selama pandemi Covid-19 dalam konteks pekerja informal, siswa, dan mahasiswa dalam merespon pandemi yang membuat keadaan normal sehari-hari berubah. Penelitian yang sekarang ini berupaya menjelaskan pengalaman yang dialami oleh pengurus organisasi kemahasiswaan yang mereka adalah mahasiswa, dan juga memiliki tanggung jawab mengerjakan tugas-tugas organisasinya di tengah pandemi Covid-19.

Teori fenomenologi digunakan dalam penelitian ini untuk memahami makna subjektif yang berkesinambungan dari individu. Fenomenologi menjelaskan makna berdasarkan pengalaman hidup seseorang secara sadar atau pengalaman beberapa individu terkait konsep atau fenomena dalam hidup mereka. Riset fenomenologis berasumsi bahwa kreativitas, kehendak bebas, dan sikap subjektif lainnya terdapat dalam diri setiap manusia. Husserls, tokoh fenomenologi, menjelaskan bahwa dunia yang subjektif dan relatif ini karena subjek membuat dunianya sendiri berdasarkan pandangannya yang subjektif dan berbeda dengan subjek lainnya (Basrowi \& Sukidin, 2002; Nurtyasrini \& Hafiar, 2016). Lebih lanjut, Alfred Schutz menjelaskan bahwa fenomenologi adalah upaya memahami tindakan, ucapan, dan interaksi yang menjadi syarat keberadaan sosial (Finlay, 2013; Goldthorpe, 1971). Posisi manusia di masyarakat berkaitan dengan tindakan manusia yang memungkinkan seseorang berkamuflase atau meniru tindakan orang lain di sekitarnya (Mulyana, 2006).

Setiap individu mungkin memiliki pengalaman yang sama, namun setiap individu memaknai pengalamannya berbeda-beda. Pengalaman satu orang dengan orang yang lain berbeda maknanya. Pemaknaan seseorang terhadap pengalaman menjadikannya bagian dari kesadaran. Tindakan atau perilaku individu muncul karena adanya kesadaran dan pemaknaan terhadap pengalamannya. Hal ini juga telah dijelaskan oleh Alfred Schutz, perilaku adalah buah dari pengalaman sadar yang didapatkan dari aktivitas yang bermakna atau dimaknai (Finlay, 2013; Goldthorpe, 1971). Pengalaman dan perilaku adalah satu kesatuan di antara subjek dan objek yang memiliki kontinuitas (Kuswarno, 2009; Utami, 2016).

Menyoal pengalaman komunikasi bahwa aktivitas komunikasi di suatu lingkungan memunculkan pengalaman komunikasi. Hal yang paling sentral dan penting untuk keberlangsungan hidup individu dan jalinan antar individu adalah komunikasi (Nurtyasrini \& Hafiar, 2016). Komunikasi adalah proses yang tidak linear karenanya di antara orang yang berinteraksi komunikasi dapat berubah-ubah (West \& Turner, 2010). Pengalaman yang dimiliki individu berawal dari peristiwa yang dialaminya secara sadar. Pengalaman yang didapatkan tersebut berisi suatu informasi atau pesan yang kemudian diolah menjadi 
pengetahuan tambahan bagi individu. Pengalaman komunikasi individu ada dari peristiwa yang mengandung unsur komunikasi, dan akan diingat oleh individu serta memiliki dampak tertentu ketika pengalaman itu dianggap penting atau khusus (Nurtyasrini \& Hafiar, 2016).

Oleh karena itu, dalam penelitian ini penulis menggunakan teori fenomenologi juga bermaksud mengkaji pengalaman komunikasi dan adaptasi teknologi komunikasi yang dilakukan oleh BEM FISIP dalam menjalankan organisasinya selama pandemi Covid-19. Menggunakan metode fenomenologi, peneliti melakukan wawancara secara daring kepada para pengurus BEM FISIP sebagai upaya memahami pengalaman komunikasi dan adaptasi teknologi komunikasi yang mereka alami. Dengan teori fenomenologi, peneliti memandang subjek penelitian memiliki makna untuk dirinya sendiri yang saling berkesinambungan satu sama lain di setiap pengalaman yang dialaminya atau dirasakan (Hakim et al., 2017; Muzzetto, 2006; Nurtyasrini \& Hafiar, 2016; Trujillo, 2018). Peneliti bertujuan menggali apa yang pengurus BEM FISIP rasakan saat harus menjalankan organisasi selama pandemi Covid-19, dan bagaimana mereka menjalankan organisasinya. Lebih lanjut, peneliti juga bertujuan menggali apa kendala yang dialami dalam menjalankan organisasinya selama pandemi, dan bagaimana kendala itu diatasi sehingga organisasinya tetap berjalan.

\section{METODE PENELITIAN}

Penelitian ini menggunakan paradigma interpretif yang berusaha mempelajari bagaimana individu-individu mengalami kehidupan mereka sehari-hari (Neuman, 2011). Mengingat permasalahan dalam penelitian cukup unik, dan membutuhkan eksplorasi pengalaman individu secara mendalam ketika menjalankan organisasi selama pandemi Covid19, maka penelitian ini menggunakan desain penelitian metode fenomenologi. Penggunaan fenomenologi untuk penelitian organisasi masih terbatas meskipun sering terjadi artikulasi kekuatannya untuk memahami pengalaman manusia (Conklin, 2007; Ehrich, 2005). Peneliti bermaksud memahami pengalaman komunikasi dan adaptasi teknologi komunikasi yang dialami salah satu organisasi kemahasiswaan dalam menjalankan organisasinya ketika pandemi Covid-19. Subjek penelitian adalah pengurus BEM FISIP UB 2020. Peneliti melakukan wawancara mendalam terhadap pengurus yang berjumlah delapan orang. Informan dalam penelitian ini adalah Presiden BEM FISIP UB, Menteri Kebijakan Publik, Menteri Inovasi dan Karya, Wakil Menteri Pengembangan Sumber Daya Mahasiswa, Kepala Biro Pusat Komunikasi dan Informasi, dan tiga staf ahli. Informan dalam penelitian ini dipilih dengan teknik snowball, dan presiden BEM FISIP sebagai key informant awal. Peneliti melakukan wawancara mendalam secara daring untuk mengumpulkan data. Teknik analisis data yang digunakan oleh peneliti dalam riset ini yakni mendeskripsikan tekstural atau struktural yang dialami oleh individu, menggabungkan deskripsi tekstural dan struktural yang didapatkan, merancang sintesis makna tekstural dan struktural, dan menyimpulkan makna yang dialami (Moustakas, 1994). 


\section{HASIL DAN PEMBAHASAN}

Berdasarkan hasil wawancara dengan pengurus BEM FISIP, peneliti memberikan paparan deskriptif atau naratif tentang perasaan mereka secara umum dalam menjalankan organisasi kemahasiswaan selama pandemi Covid-19. Peneliti juga melakukan analisis tematik tentang kelebihan dan kekurangan menjalankan organisasi selama pandemi Covid-19 menurut pengurus BEM FISIP. Lebih lanjut, peneliti juga memaparkan kendala serta solusi yang diterapkan oleh mereka agar organisasi dapat berjalan baik selama pandemi Covid-19.

\section{Perasaan Pengurus Menjalankan Organisasi Selama Pandemi Covid-19}

Pengurus BEM FISIP memahami kebijakan Universitas Brawijaya yang mewajibkan semua aktivitas akademik dan non-akademik tidak boleh dilaksanakan di kampus pada pertengahan Maret 2020, termasuk aktivitas organisasi kemahasiswaan. Kebijakan ini membuat seluruh aktivitas organisasi BEM FISIP harus dilaksanakan dengan cara berbeda dari apa yang sudah direncanakan di awal periode kepengurusan. Terdapat dua perasaan yang tertangkap dari pengalaman para pengurus yakni perasaan optimis dan perasaan kecewa.

Berdasarkan wawancara dengan Presiden BEM FISIP, situasi ini tidak untuk diratapi melainkan organisasi harus langsung adaptif dengan keadaan dan mencari solusi. Pandemi Covid-19 adalah tantangan bagi organisasi BEM FISIP (A.D Prasaja, wawancara pribadi, 1 Desember 2020). Pandemi Covid-19 adalah tantangan untuk organisasi berpikir kreatif menemukan solusi dalam situasi yang tidak pasti karena pandemic Covid-19. Hal ini menggambarkan perasaan optimis dari pengurus dalam menjalankan organisasi mahasiswa selama pandemi Covid-19.

Di awal kebijakan aktivitas organisasi tidak boleh dilakukan di kampus, beberapa pengurus merasa sedih dan terkejut karena situasi ini tidak pernah terbayangkan oleh mereka khususnya para staf. Aktivitas organisasi yang sejatinya menjadi tempat mereka untuk berkembang tiba-tiba harus berubah, dan tidak tahu apa yang akan mereka lakukan di organisasinya. Berdasarkan wawancara yang dilakukan, mereka menyatakan memiliki ekspektasi khusus saat memutuskan untuk mengikuti organisasi BEM FISIP, namun situasi pandemi membuat harapan mereka tidak terwujud. Harapan mereka sebagai pengurus di antaranya mereka dapat berbagi satu sama lain di sekretariat BEM, menggelar program kerja, dan rapat dengan tatap muka (Syawal, wawancara pribadi, 4 Desember 2020). Hal ini menggambarkan perasaan kecewa yang dialami oleh pengurus.

Lebih lanjut, bagi mereka yang merasa sebagai orang ekstrover, mereka merasa pengembangan diri sebagai aktivis organisasi tidak didapatkan secara optimal di tengah pandemi Covid-19. Menjalankan organisasi selama pandemi menurut sebagian dari mereka membuat badan capek karena intensitas di depan layar laptop dan layar handphone lebih banyak. Bagi mereka pertemuan langsung dengan pengurus organisasi dapat mengurangi rasa capek tersebut. Namun, ternyata bagi mereka yang merasa sebagai orang introver, menjalani aktivitas organisasi selama pandemi Covid-19 membuat mereka lebih nyaman karena tidak banyak bertemu orang. Mereka tidak merasa ada beban dan habis energi berada di tengahtengah banyak orang. Justru, mereka dapat lebih mengembangkan diri dalam situasi organisasi yang harus adaptif dengan pandemi Covid-19. 


\section{Kelebihan dan Kekurangan Menjalankan Organisasi Selama Pandemi}

Di satu sisi, beberapa pengurus merasakan bahwa menjalankan organisasi selama pandemi ini memiliki kelebihan yang mungkin tidak mereka dapatkan ketika organisasi ini dijalankan secara normal atau tatap muka langsung (Tabel 1). Berdasarkan wawancara yang dilakukan, ada pengurus yang mengalami ekspansi program kerja jadi lebih luas dari sebelumnya. Program kerja yang digelar secara daring memungkinkan mahasiswa di luar FISIP UB bahkan di luar Universitas Brawijaya bisa mengikuti agenda-agenda yang digelar oleh BEM FISIP seperti acara-acara webinar, konten berbagi di Spotify, konten Youtube, dan konten Instagram. Selain itu, program kerja yang digelar secara daring memungkinkan untuk mendatangkan narasumber tokoh-tokoh nasional. Acara yang digelar daring tidak mengharuskan narasumber yang diundang untuk datang ke Malang sehingga organisasi tidak harus mengeluarkan anggaran khusus untuk akomodasi narasumber. Hal inilah yang membuat mereka berani untuk mengundang tokoh-tokoh nasional.

Tabel 1. Kelebihan dan Kekurangan Menjalankan Organisasi Selama Pandemi

\begin{tabular}{ll}
\hline Kelebihan & Kekurangan \\
\hline Ekspansi target program kerja yang luas & Kontrol kualitas kurang berjalan \\
Mudah melibatkan tokoh nasional dalam program kerja & Kurang bagus untuk kesehatan \\
Media sosial BEM FISIP menjadi ramai & Keakraban kurang terwujud \\
Konten berbentuk digital banyak & Rasa dalam program kerja kurang \\
Membuat diri eksplorasi hal-hal baru & Tidak terasa kerja komunal \\
Wujud konkret organisasi 4.0 & Jenuh dengan rutinitas via daring \\
Produktivitas meningkat & Terlalu banyak informasi \\
\hline
\end{tabular}

Sumber: Data diolah peneliti (2020)

Program kerja tatap muka yang harus dikonversi menjadi program kerja secara daring membuat media sosial yang dimiliki BEM FISIP menjadi ramai. Semua kementerian membuat program kerja berupa konten yang bisa dibagikan di berbagai media sosial dan platform digital BEM FISIP. Jika dulu konten media sosial hanya berupa poster dan potongan dokumentasi acara, di saat pandemi berisi konten-konten yang merupakan hasil konversi dari program kerja yang harusnya tatap muka. Mereka mengadakan webinar, dan rekamannya dibagikan di Youtube atau mereka melakukan live streaming wawancara dengan satu figur dan hasil videonya dibagikan di Instagram. Hal ini membuat konten-konten BEM FISIP yang berbentuk digital menjadi lebih banyak di saat pandemi Covid-19. Banyaknya konten digital ini akhirnya juga menjadi kelebihan tersendiri karena konten tersebut shareable, bisa dinikmati oleh siapa saja yang mengakses media digital sehingga kebermanfaatannya meluas.

Menjalankan organisasi di tengah pandemi Covid-19 juga membuat pengurus dapat mengeksplorasi hal-hal baru yang mungkin sebelumnya tidak terpikirkan. Kondisi krisis membuat mereka terpacu untuk berpikir mencari solusi-solusi yang membuat organisasinya dan program kerjanya tetap terlaksana dengan baik dan lancar. Situasi pandemi merangsang kreativitas pengurus dalam menjalankan organisasinya seperti optimalisasi penggunaan media digital. Konversi program kerja yang awalnya tatap muka menjadi program kerja yang digelar secara daring atau memanfaatkan media digital menjadikan BEM FISIP benar menjadi organisasi yang 4.0, seperti yang banyak digaungkan orang bahwa saat ini adalah era 4.0. Lebih lanjut, bagi beberapa pengurus kondisi pandemi ini malah meningkatkan produktivitas mereka karena mereka banyak melakukan aktivitas di rumah, tanpa gangguan hal-hal yang membuat 
mereka tidak fokus. Mereka lebih menemukan titik kenyamanan karena dapat berorganisasi tanpa berkumpul di tempat yang ramai. Perasaan semacam ini diungkapkan oleh mereka yang merasa diri mereka adalah introver, orang yang merasa mendapatkan energi ketika mereka di kesendirian.

Di sisi yang lain, menjalankan organisasi selama pandemi ini menurut beberapa pengurus juga ada kekurangan yang dirasakan. Ketika situasi normal pengurus merasa mudah untuk melakukan kontrol terhadap kualitas pekerjaan timnya karena bisa berjumpa saat perkuliahan atau berjumpa langsung di sekretariat. Namun, di situasi pandemi quality control kurang berjalan. Hal ini disadari oleh pengurus karena bagi mereka di saat pandemi semacam ini yang penting program kerja terlaksana dulu, bahkan beberapa dari mereka menyatakan meskipun program kerjanya kurang sempurna akan dimaklumi karena situasi pandemi ini.

Beberapa pengurus juga mengalami situasi pandemi ini mengurangi keakraban di antara anggota organisasi. Mereka kurang merasakan kebersamaan yang hanya terjalin via teknologi komunikasi seperti Google Meet, Zoom atau instant messaging group. Selain itu, semua koordinasi program kerja juga dilakukan melalui daring sehingga mereka kurang merasakan sense of belonging dari program kerja yang mereka buat. Mereka merasa seperti bekerja sendiri meskipun sebenarnya program kerja itu direncanakan bersama-sama, namun kondisi yang berjauhan membuat mereka tidak merasakan suasana yang komunal dalam aktivitas organisasi.

Lebih lanjut, ada pengurus yang juga merasakan jenuh dengan rutinitas organisasi yang serba daring. Mereka merasa lelah karena kuliah via daring, diskusi kelompok juga daring, ditambah menjalankan organisasi secara daring. Bagi mereka, situasi tersebut membuat jenuh, dan merasa kurang baik untuk kesehatan mereka karena terlalu lama duduk dan menatap layar untuk mengikuti perkuliahan, mengerjakan tugas kuliah ditambah tugas dari organisasi yang juga mengharuskan mereka menatap layar lagi. Mereka juga merasakan situasi pandemi ini membuat mereka mengalami banjir informasi dikarenakan semua informasi terkait koordinasi dan agenda organisasi mereka terima dalam satu perangkat yakni handphone. Hal ini membuat mereka seringkali terdistorsi dalam menyerap sebuah informasi karena banyaknya informasi yang mereka terima sehingga kadang terlewat informasi yang harusnya penting untuk diprioritaskan.

\section{Kendala dan Solusi dalam Menjalankan Organisasi Selama Pandemi}

Berdasarkan hasil wawancara yang dilakukan, peneliti menemukan bahwa pengurus BEM FISIP mengalami berbagai kendala dalam menjalankan organisasi selama pandemi Covid-19, namun juga mereka memiliki solusi atas kendala yang mereka alami. Ada pengurus yang menyatakan jika situasi pandemi ini awalnya cukup menyulitkan untuk mereka. Mereka bingung organisasi yang adaptif dengan pandemi harus seperti apa dan bagaimana idealnya. Hal ini berkaitan dengan program kerja yang mereka rancang. Situasi pandemi mengubah apa yang sudah mereka rencanakan, dan mereka tidak memiliki rencana cadangan yang memang sengaja dipersiapkan ketika ada krisis menimpa organisasi. Oleh karena itu, mereka cukup membutuhkan waktu untuk bisa adaptif.

Solusi yang kemudian mereka terapkan agar adaptasi organisasi di tengah pandemi lebih cepat adalah penyederhanaan program kerja, dan mengupayakan program kerja dapat dilaksanakan secara daring. Mereka mencoba meyakinkan diri bahwa tantangan di masa 
pandemi ini akan bisa dilalui, dan organisasi akan berjalan baik-baik saja. Penyederhanaan program kerja ini tidak kemudian mengurangi dampak dari program kerja melainkan memiliki kelebihan yakni semakin meluasnya dampak karena target sasaran program yang tidak hanya mahasiswa internal saja melainkan masyarakat umum juga dapat mengikuti, seperti yang telah dipaparkan di aspek kelebihan menjalankan organisasi di tengah pandemi.

Kendala yang juga dialami oleh beberapa pengurus adalah kesalahpahaman antar pengurus karena komunikasi yang kurang baik. Hal ini karena interaksi atau proses komunikasi di antara mereka tidak terjadi secara tatap muka. Koordinasi yang dilakukan dari jarak jauh sering kali memperbesar ketidakpastian apakah masing-masing sudah mengerjakan hal yang sudah menjadi pekerjaannya. Ditambah lagi, terkadang ada pengurus yang tidak responsif di grup pengurus sehingga menimbulkan tanda tanya dan prasangka kurang baik terhadap rekan organisasinya. Situasi semacam itu tidak terhindarkan selama mereka menjalankan organisasi dari jarak jauh. Ditambah lagi, tidak setiap orang yang menjadi pengurus di BEM FISIP memiliki perangkat teknologi yang bagus, dan berlokasi di tempat yang mendapatkan sinyal bagus yang membuat komunikasi dimediasi teknologi komunikasi jarak jauh berjalan lancar.

Solusi yang mereka lalukan selama ini adalah memastikan koordinasi berjalan baik dengan membudayakan untuk konfirmasi ketika mengalami masalah di tempat masing-masing sehingga tidak timbul perasaan buruk sangka meninggalkan tanggung jawab antar anggota. Mereka juga memastikan ruang komunikasi antar pengurus harus ada salah satunya dengan memanfaatkan grup chatting sebaik mungkin. Selain itu, untuk mengurangi kejenuhan dalam berorganisasi beberapa pengurus juga memiliki inisiatif untuk melakukan agenda keakraban meski dilakukan secara daring misalnya dengan melakukan Zoom Meeting namun tidak untuk membahas program kerja, melainkan untuk bermain games online bersama. Hal ini menurut mereka dapat mencairkan suasana sehingga sesama pengurus semakin dekat dan saling memahami satu sama lain, meskipun kedekatan yang dibangun dari pertemuan tatap muka tetap tidak tergantikan.

Tabel 2. Kendala dan solusi saat menjalankan organisasi selama Pandemi

\begin{tabular}{|l|l|}
\hline \multicolumn{1}{|c|}{ Kendala } & \multicolumn{1}{c|}{ Solusi } \\
\hline Proses adaptasi organisasi yang kurang cepat & - Simplifikasi program kerja \\
& $-\begin{array}{l}\text { Meyakinkan semua anggota bahwa organisasi } \\
\text { akan berjalan baik-baik saja }\end{array}$ \\
\hline $\begin{array}{l}\text { Kesalahpahaman antar pengurus karena komunikasi } \\
\text { yang terpisah jarak atau perangkat tidak mendukung }\end{array}$ & - Koordinasi harus diutamakan \\
& - Membuka ruang komunikasi antar pengurus \\
& - Menjalankan bonding dengan main games \\
\hline Program kerja membuat pengurus burnout & - Sistem jam kerja yang jelas \\
\hline Adopsi teknologi komunikasi yang baru & - Penambahan staf magang \\
\hline
\end{tabular}

Sumber: Data diolah peneliti (2020)

Lebih lanjut, kendala yang dialami oleh beberapa pengurus adalah program kerja yang menumpuk. Sebagai contoh, hal ini dialami oleh pengurus yang bertugas di Biro Komunikasi dan Informasi. Mereka merasakan semua kementerian meminta desain alat publikasi dan editing video kepada Biro Komunikasi dan Informasi. Situasi ini wajar karena hampir semua kementerian program kerjanya berbentuk digital ketika pandemi, namun hal tersebut ternyata membuat pengurus di Biro Komunikasi dan Informasi merasa beban pekerjaannya berlebihan. 
Oleh karena itu, mereka menyiapkan skema jam kerja yang itu adalah jam mereka aktif untuk pekerjaan-pekerjaan menyangkut organisasi. Di luar jam kerja yang sudah ditentukan mereka tidak akan melayani permintaan pekerjaan terkait kebutuhan organisasi. Hal ini sempat mengganggu jalannya program kerja organisasi bahkan memicu terjadinya kesalahpahaman dengan pengurus lain. Akhirnya solusi berikutnya adalah melakukan penambahan staf magang agar tanggung jawab pekerjaan dapat lebih terbagi.

Penggunaan teknologi komunikasi untuk mendukung terlaksananya program kerja organisasi juga sempat menjadi kendala bagi beberapa pengurus BEM FISIP. Mereka baru pertama kali menggunakan dan belum terbiasa dengan teknologi komunikasi yang digunakan seperti Zoom dan Google Meet sehingga perlu ada pengarahan khusus untuk setiap pengurus dapat menggunakannya dengan baik. Hal ini wajar meskipun dari semua pengurus adalah mahasiswa namun memang tidak semua dari pengurus langsung familiar dalam menggunakan Google Meet atau Zoom Meeting. Permasalahan ini terjadi sebentar saja karena memang hanya butuh pembiasaan saja dari para pengurus.

\section{Pengurus Introver dan Ekstrover dalam Menjalankan Organisasi Selama Pandemi}

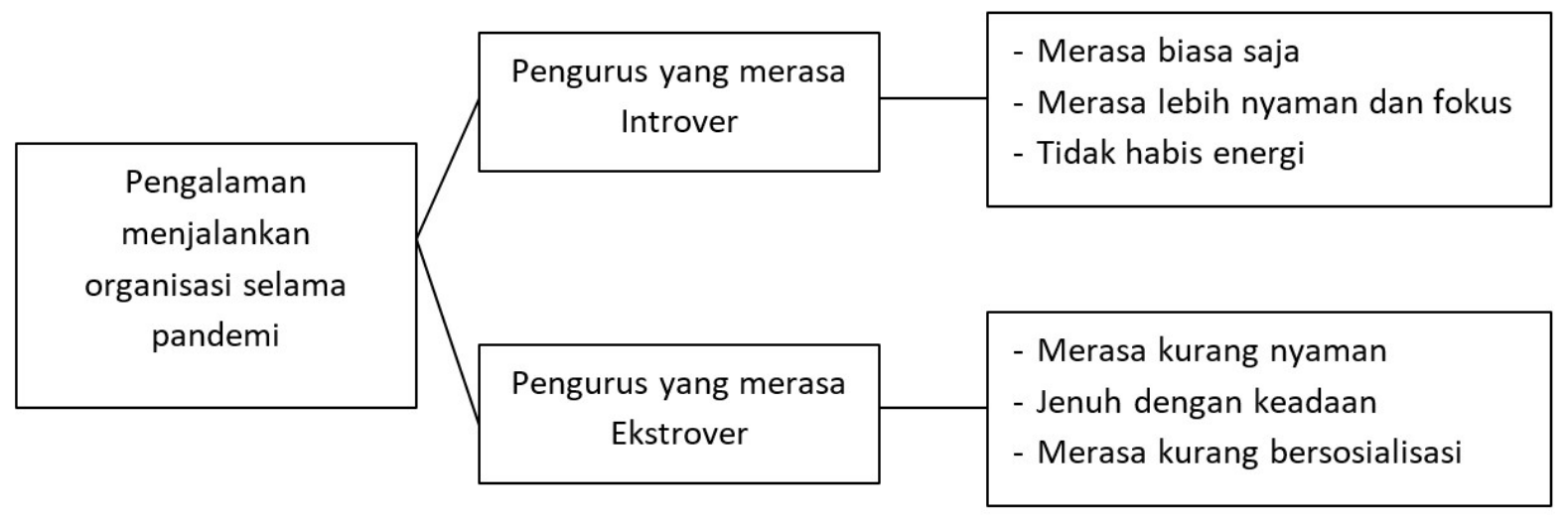

Sumber: Data diolah peneliti (2020)

\section{Gambar 1. Pengalaman Pengurus Yang Merasa Introver Dan Ekstrover}

Peneliti menemukan ada perbedaan perasaan di antara mereka yang introver dan ektrover (Gambar 1). Pengurus yang introver merasa biasa saja dengan suasana berorganisasi yang harus beradaptasi dengan pandemi Covid-19. Mereka bahkan merasa lebih nyaman dan fokus dalam menjalankan aktivitas organisasi karena tidak banyak bertemu dengan orang atau berkumpul ramai-ramai, meskipun bagi mereka berkomunikasi tatap muka tetaplah hal yang penting. Namun, keadaan pandemi yang mengharuskan mereka berorganisasi dari rumah adalah sebuah keuntungan. Hal berbeda justru dialami oleh pengurus yang merasa dirinya ekstrover. Mereka merasa ekspektasinya di organisasi tidak terpenuhi. Mereka berharap bisa bertemu banyak rekan-rekan di organisasi, bertemu dengan seniornya di kampus, melakukan rapat bersama secara tatap muka terkait program kerja organisasi, namun itu tidak bisa mereka dapatkan karena situasi pandemi Covid-19 yang mengubah cara berorganisasi untuk sementara ini.

\section{Adopsi Teknologi Komunikasi selama Pandemi Covid-19}


Kebijakan universitas mengenai situasi pandemi Covid-19 yang memaksa aktivitas kemahasiswaan dilaksanakan dengan cara berbeda membuat organisasi menjadi adaptif. BEM FISIP sebagai organisasi kemahasiswaan tertinggi di lingkungan FISIP UB langsung berinisiatif untuk berlangganan aplikasi meeting dan webinar yakni Zoom Premium. Berdasarkan wawancara dengan Kepala Biro Pusat Komunikasi dan Informasi BEM FISIP, berlangganan Zoom ini menjadi alternatif ruang kolektif bagi semua pengurus. Mereka menggunakan Zoom untuk melaksanakan program kerja yang menjangkau mahasiswa, dan sekaligus untuk ruang diskusi antar pengurus ketika merumuskan rencana eksekusi program kerja (Gilang, wawancara pribadi, 4 Desember 2020).

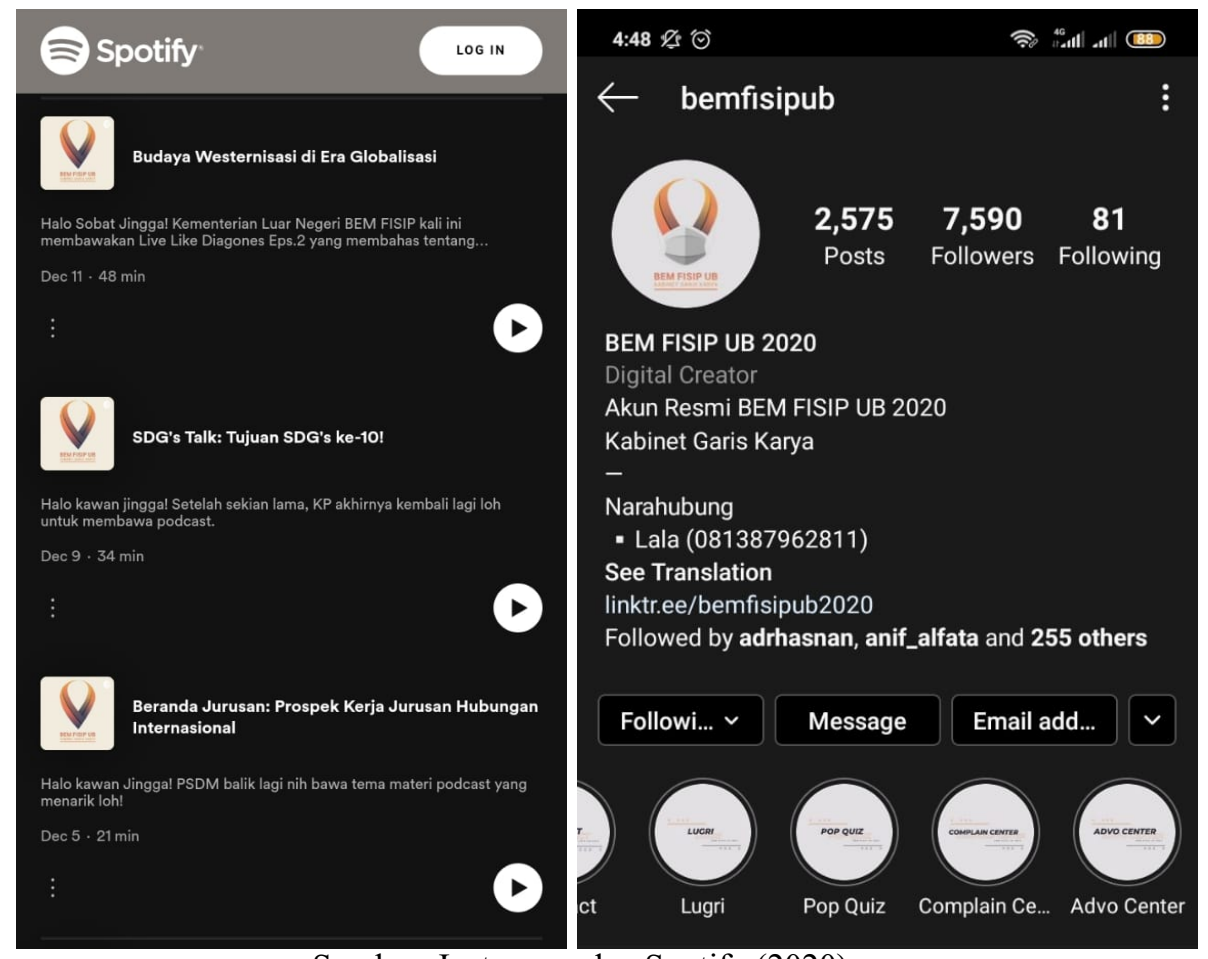

Sumber: Instagram dan Spotify (2020)

Gambar 2. Instagram dan Spotify BEM FISIP

BEM FISIP UB juga memanfaatkan teknologi komunikasi Anchor FM dan Spotify sebagai media podcast yang bisa didengarkan oleh seluruh mahasiswa FISIP bahkan umum. Media podcast yang dimiliki FISIP UB berisi konten-konten pengembangan diri. Berdasarkan wawancara yang dilakukan kepada wakil menteri PSDM BEM FISIP, pemanfaatan media podcast ini awalnya sudah dirancang oleh kementeriannya sebagai platform berbagi ilmu yang kekinian bahkan sebelum ada kebijakan work from Home dalam rangka meminimalisasi penyebaran virus Corona. Namun adanya work from home membuat konten podcast BEM FISIP jadi lebih banyak karena semua kementerian juga ingin memanfaatkan media podcast ini sebagai perpanjangan tangan program kerjanya yang harus dilakukan secara daring.

Adopsi teknologi komunikasi seperti Zoom, Google Meet, dan Spotify menurut pengurus sangat membantu dalam pelaksanaan program kerja mereka yang banyak melalui daring karena pandemi Covid-19. Teknologi komunikasi ini adalah penunjang utama, dan satusatunya jalan untuk berkomunikasi dengan masyarakat FISIP UB, dan menunjukkan eksistensi BEM FISIP kepada masyarakat luas. Hal ini lepas dari beberapa program kerja BEM FISIP 
2020 yang memang tetap harus dilaksanakan secara tatap muka langsung dengan target program seperti pengabdian masyarakat ke desa.

Lebih lanjut, beberapa pengurus mengalami kesulitan saat awal-awal adopsi beberapa teknologi komunikasi untuk menjalankan program kerja dan koordinasi antar tim seperti penggunaan Zoom dan Google Meet. Hal ini karena teknologi komunikasi ini juga baru mereka gunakan ketika pandemi, namun pada akhirnya mereka terbiasa karena dituntut bisa. Meskipun begitu, ada beberapa pengurus yang langsung adaptif dengan penggunaan teknologi komunikasi yang baru digunakan di saat pandemi karena mereka berani mencoba-coba teknologi komunikasi yang digunakan dan mencari tahu fitur-fitur dan cara penggunaannya.

Perasaan yang dialami oleh pengurus BEM FISIP dalam menjalankan organisasi di tengah pandemi memiliki makna khusus untuk dirinya sendiri. Makna tersebut berhubungan dengan bagian-bagian yang dirasakan oleh masing-masing individu atau aktor sosial dalam tindakan-tindakan yang dilakukannya (Aldira, 2020; Muzzetto, 2006). Makna tersebut saling berkesinambungan satu sama lain di setiap pengalaman yang dialaminya atau dirasakan (Hakim et al., 2017; Muzzetto, 2006; Nurtyasrini \& Hafiar, 2016). Fenomenologi berupaya menjelaskan pengalaman seorang individu dan pemaknaan individu atas apa yang dialami dalam kehidupan sehari-harinya (Mulyana, 2006), dalam konteks ini pengalaman sebagai pengurus sebuah organisasi kemahasiswaan yang menjalankan program kerjanya di era pandemi. Cara individu membangun makna bergantung pada pengalaman komunikasi individu masing-masing. Proses komunikasi antar individu yang erat kaitannya dengan berbagi makna berupa simbol-simbol atau pesan akan menghasilkan pengalaman komunikasi (Hafiar, 2012; Nurtyasrini \& Hafiar, 2016). Interaksi antar pengurus BEM FISIP UB memungkinkan mereka bertukar pesan mengenai perasaan menjalankan organisasi di tengah pandemi. Mereka biasanya berbagi informasi, saling koordinasi, menerima keluh dan kesah satu sama lain, dan memberikan semangat kepada rekan-rekannya.

Penelitian ini menujukkan bahwa pengurus memiliki perasaan masing-masing yang berbeda satu sama lain terkait pengalaman mereka beradaptasi saat pandemi Covid-19. Penelitian ini menemukan bahwa perasaan optimis yang dimiliki oleh beberapa pengurus dalam menjalankan organisasi di tengah pandemi terbukti berbeda dengan yang dialami oleh beberapa pengurus lainnya. Namun, perbedaan perasaan ini justru sebenarnya dapat membangun keseiramaan di antara para pengurus untuk meminimalisasi miss-komunikasi dan saling memahami di antara mereka dalam menjalankan program kerja.

Lebih lanjut, penelitian ini memetakan ungkapan-ungkapan dari para pengurus berdasarkan pengalaman mereka menjalankan organisiasi di era pandemi, dan terkategorikan sebagai kelebihan dan kelemahan yang dirasakan dalam menjalankan organisasi di tengah pandemi. Hasil penelitian ini selaras dengan penelitian yang dilakukan oleh Hidayat dan Noeraida (2020) dan Mustopa dan Hidayat (2020). Para siswa dan mahasiswa melihat situasi pandemi ini memiliki kekurangan dan kelebihan dalam proses pendidikan. Kekurangan yang dialami misalnya tidak dapat menangkap pesan non-verbal dan aktivitas menjadi kurang dinamis. Kelebihan yang dialami misalnya lebih fleksibel, dan tidak terbatas ruang dan waktu. Penelitian ini menguatkan bahwa setiap individu memiliki pengalaman subjektif yang didapatkan dari proses komunikasi. Menyoal hal tersebut semakin menjelaskan bahwa aktivitas komunikasi di suatu lingkungan memunculkan pengalaman komunikasi. Nurtyasrini dan 
Hafiar (2016) juga telah menjelaskan hal yang paling sentral dan penting untuk keberlangsungan hidup individu dan jalinan antar individu adalah komunikasi.

Dalam penelitian ini, pengurus BEM FISIP melihat adanya kekurangan dalam menjalankan organisasi di tengah pandemi ini seperti rasa jenuh melakukan aktivitas organisasi secara daring dan kurangnya rasa kerja komunal. Selain itu juga ada kelebihan yang dirasakan seperti produktivitas malah meningkat dan terbukanya kesempatan untuk eksplorasi kemampuan diri. Pengalaman-pengalaman yang dirasakan oleh mereka ini bersifat subjektif, dan terikat dengan konteks ruang dan waktu. Pengalaman yang dirasakan oleh siswa dan mahasiswa tersebut akan berbeda meskipun dalam kejadian yang sama yakni adaptasi kegiatan di tengah pandemi Covid-19. Implikasi dari pengalaman subjektif yang dirasakan oleh pengurus ini yakni pimpinan organisasi perlu memperhatikan ekspektasi dari anggota organisasinya dalam mengambil keputusan sehingga aspek kekurangan yang dialami oleh pengurus di masa pandemi tidak menganggu kinerja, sedangkan aspek kelebihan dapat dioptimalkan menuju tercapainya visi dan misi organisasi.

Lebih lanjut, perbedaan respon dan pengalaman menjalankan organisasi di situasi pandemi Covid-19 juga berkaitan dengan kemampuan penyesuaian diri yang dipengaruhi oleh konsep diri seorang individu. Feist dan Feist (2010) mengungkapkan bahwa konsep diri berdampak terhadap persepsi dan tindakan individu. Konsep diri adalah impresi individu secara keseluruhan terhadap dirinya sendiri meliputi penilaiannya terhadap diri sendiri, penilaian mengenai sosok dirinya dari orang lain, dan penilaiannya mengenai ekspektasi dirinya (Burns, 1993). Dalam konteks penelitian ini terlihat bahwa pengurus yang memiliki konsep diri sebagai seorang introver memiliki pengalaman yang berbeda dengan pengurus yang memiliki konsep diri sebagai seorang ektrover. Penyesuaian diri dalam aktivitas organisasi di masa pandemi Covid-19 ternyata lebih bisa dilakukan oleh pengurus yang introver dibandingkan pengurus yang ekstrover. Temuan ini membangun implikasi bahwa kepribadian anggota adalah aspek yang juga harus diperhatikan oleh pimpinan organisasi dalam membagi tanggung jawab organisasi kepada anggota-anggotanya.

Situasi pandemi Covid-19 menuntut organisasi termasuk BEM FISIP untuk adaptif dalam menjalankan organisasinya. Salah satu cara untuk adaptif adalah dengan mengadopsi teknologi komunikasi yang memungkinkan mereka berkomunikasi jarak jauh, dan dapat menjalankan program kerja secara daring. Menurut Rogers (2019), adopsi adalah keputusan untuk memanfaatkan inovasi sebagai tindakan terbaik yang tersedia. Temuan penelitian ini menunjukkan BEM FISIP telah mengadopsi beberapa teknologi komunikasi di saat pandemi Covid-19. Penggunaan teknologi komunikasi seperti Zoom dan Google Meet oleh BEM FISIP merupakan pilihan terbaik dan langkah tepat yang dilakukan oleh BEM FISIP untuk menyukseskan agenda organisasinya di tengah tantangan pandemi Covid-19.

Dalam penelitian ini, aspek adopsi teknologi komunikasi memang masih belum komprehensif digali dan dikaitkan dengan konsep-konsep adopsi teknologi. Penelitian ini hanya mendeskripsikan saja jika adopsi teknologi komunikasi dilakukan oleh BEM FISIP karena urgensi atau keadaan yang mengharuskan mereka menggunakan teknologi tertentu. Penelitian lebih lanjut terkait adopsi teknologi komunikasi oleh organisasi khususnya di saat krisis menarik untuk dilakukan oleh peneliti selanjutnya. 


\section{SIMPULAN}

Perubahan cara berorganisasi karena harus beradaptasi dengan situasi pandemi Covid19 menanamkan pengalaman tersendiri bagi pengurus BEM FISIP UB periode 2019-2020. Mereka merasakan kelebihan dari cara berorganisasi yang baru, namun juga merasakan ada kekurangan dari aktivitas organisasi di era pandemi. Penelitian ini juga menemukan bahwa pengurus juga merasakan adanya kendala dalam menjalankan organisasi dengan cara yang baru ini, namun mereka juga memiliki solusi penyelesaian dari kendala yang dialaminya sehingga mereka bisa adaptif. Temuan menarik lainnya yakni ada perbedaan persepsi antara pengurus yang introver dan pengurus yang ekstrover dalam merespon cara baru berorganisasi yang adaptif dengan situasi pandemi. Pengurus yang ekstrover merasa kurang puas dengan aktivitas organisasi yang dijalaninya, sedangkan pengurus yang introver merasa biasa saja dan lebih bisa menghabiskan waktu banyak untuk fokus dengan pekerjaan organisasinya tanpa menghabiskan banyak energi bertemu banyak orang.

Rekomendasi berdasarkan hasil penelitian ini adalah pimpinan organisasi harus memperhatikan karakter diri dan harapan para pengurusnya agar dapat memutuskan kebijakan yang tepat selama menjalankan organisasi di tengah pandemi Covid-19. Lebih lanjut, peneliti selanjutnya dapat melakukan penelitian secara kuantitatif untuk menguji aspek-aspek iklim organisasi di tengah pandemi yang dimediasi oleh karakteristik individu, persepsi, dan ekspektasi individu terhadap organisasinya. Peneliti juga dapat melakukan penelitian lebih mendalam terkait adopsi teknologi komunikasi di era pandemi atau kondisi krisis sejenis.

\section{UCAPAN TERIMA KASIH}

Penulis mengucapkan terima kasih kepada para pengurus Badan Eksekutif Mahasiswa, Fakultas Ilmu Sosial dan Ilmu Politik, Universitas Brawijaya yang telah menerima penulis untuk melakukan wawancara dalam rangka penelitian ini. Penulis juga mengucapkan terima kasih kepada Lembaga Pengelola Dana Pendidikan (LPDP) sebagai pemberi dana studi. Ucapan terima kasih juga kepada reviewer dan editor yang telah memberikan saran perbaikan untuk menjadikan artikel ini lebih baik.

\section{DAFTAR PUSTAKA}

Abidah, A., Hidayatullah, H. N., Simamora, R. M., Fehabutar, D., \& Mutakinati, L. (2020). The Impact of Covid-19 to Indonesian Education and Its Relation to the Philosophy of "Merdeka Belajar." Studies in Philosophy of Science and Education, 1(1), 38-49. https://doi.org/10.46627/sipose.v1i1.9

Aldira, N. P. (2020). Motif Penggunaan Fitur Stories Highlight Instagram sebagai Memori $\begin{array}{lllll}\text { Media bagi Generasi Milenial. Avant } & \text { Garde, }\end{array}$ https://doi.org/10.36080/ag.v8i2.1180

Basrowi, \& Sukidin. (2002). Metode penelitian kualitatif: perspektif mikro. Surabaya: Insan Cendekia.

Burns, R. B. (1993). Konsep Diri: Teori, pengukuran, perkembangan dan perilaku. Jakarta: Arcan.

Conklin, T. A. (2007). Method or Madness: Phenomenology as Knowledge Creator. Journal of Management Inquiry, 16(3), 275-287. https://doi.org/10.1177/1056492607306023 
Ehrich, L. (2005). Revisiting Phenomenology: Its potential for management research. In K. Grint (Ed.), British Academy of Management Conference Proceedings 2005: Challenges of Organizations in Global Markets (Issue Said Business School, Oxford University., pp. 1-13). British Academy of Management. http://eprints.qut.edu.au/2893/1/2893.pdf

Feist, J. dan F. G. J. (2010). Teori Kepribadian. Edisi 7 Buku II. Alih Bahasa: Sjahputri S P. Jakarta: Salemba Humanika.

Finlay, L. (2013). Unfolding the Phenomenological Research Process. Journal of Humanistic Psychology, 53(2), 172-201. https://doi.org/10.1177/0022167812453877

Goldthorpe, J. H. (1971). The Phenomenology of the Social World , by Alfred Schutz. . Journal of the British Society for Phenomenology, 2(3), 81-84. https://doi.org/10.1080/00071773.1971.11006206

Hafiar, H. (2012). Cacat Dan Prestasi Melalui Pengalaman Komunikasi Atlet Penyandang Cacat. Indonesian Journal of Dialectics, 2(1).

Hakim, A. Z., Hafiar, H., \& Puspitasari, L. (2017). Pengalaman Komunikasi Guru Homeschooling. Edutech, 16(2), 189. https://doi.org/10.17509/e.v16i2.4125

Hidayat, D., \& Noeraida. (2020). Pengalaman Komunikasi Siswa Melakukan Kelas Online Selama Pandemi Covid - 19. JIKE Jurnal Ilmu Komunikasi Efek, 3(1), 172-182.

Khasanah, D. R. A. U., Pramudibyanto, H., \& Widuroyekti, B. (2020). Pendidikan Dalam Masa Pandemi Covid-19. Jurnal Sinestesia, 10(1), 41-48. https://sinestesia.pustaka.my.id/journal/article/view/44

Kuswarno, E. (2009). Metodologi Penelitian Komunikasi: Fenomenologi, Kosepsi, Pedoman dan Contoh Penelitiannya. Bandung: Widya Padjadjaran.

Moustakas, C. (1994). Phenomenological research methods. Thousand Oaks California: SAGE Publications. https://doi.org/10.4135/9781412995658

Mulyana, D. (2006). Metodologi penelitian kualitatif. Bandung: PT. Remaja Rosdakarya.

Mustopa, A. J., \& Hidayat, D. (2020). Pengalaman Mahasiswa Saat Kelas Online Menggunakan Aplikasi Zoom Cloud Meeting Selama Covid-19. Jurnal Digital Media \& Relationship, 2(2), 75-84.

Muzzetto, L. (2006). Time and Meaning in Alfred Schütz. Time \& Society, 15(1), 5-31. https://doi.org/10.1177/0961463X06061334

Neuman, W. L. (2011). Social Research Methods: Qualitative and Quantitative Approaches. New Jersey: Pearson Education.

Nurtyasrini, S., \& Hafiar, H. (2016). Pengalaman Komunikasi Pemulung Tentang Pemeliharaan Kesehatan Diri Dan Lingkungan Di TPA Bantar Gebang. Jurnal Kajian Komunikasi, 4(2), 219-228. https://doi.org/10.24198/jkk.vol4n2.9

Prasetya, A., \& Hidayat, D. (2020). Pengalaman Pekerja Informal di Tengah Pandemi Covid19 di Kota Bandung. Jurnal Komunikasi, Masyarakat Dan Keamanan (KOMASKAM), 2(2), 16-32.

Rogers, E. M., Singhal, A., \& Quinlan, M. M. (2019). Diffusion of innovations. In D. W. Stacks, M. B. Salwen, \& K. C. Eichhorn (Eds.), An Integrated Approach to Communication Theory and Research, Third Edition. https://doi.org/10.4324/9780203710753-35

Sohrabi, C., Alsafi, Z., O’Neill, N., Khan, M., Kerwan, A., Al-Jabir, A., Iosifidis, C., \& Agha, 
R. (2020). World Health Organization declares global emergency: A review of the 2019 novel coronavirus (COVID-19). International Journal of Surgery, 76, 71-76. https://doi.org/10.1016/j.ijsu.2020.02.034

Trujillo, J. (2018). Intersubjectivity and the Sociology of Alfred Schutz. Bulletin d'analyse Phénoménologique, 14(7), 1-30. https://popups.uliege.be/1782-2041/

Utami, N. (2016). Pengalaman Komunikasi Keluarga Istri Yang Berpendapatan Lebih Besar Dari Suami. Jurnal Kajian Komunikasi, 4(1), 95-108. https://doi.org/10.24198/jkk.vol4n1.9

West, R. L., \& Turner, L. H. (2010). Introducing communication theory: Analysis and application. New York: McGraw-Hill. 